\title{
Adult Type Ovarian Granulosa Cell Tumor
}

National Cancer Institute

\section{Source}

National Cancer Institute. Adult Type Ovarian Granulosa Cell Tumor. NCI Thesaurus.

Code C7288.

A granulosa cell tumor that affects middle aged or postmenopausal women. Patients may present with uterine bleeding. 